\title{
Quantification of Total and Soluble Inorganic Phosphate
}

Vicki Knowles and William Plaxton*

\section{Department of Biology, Queen's University, Kingston, Canada}

*For correspondence: plaxton@queensu.ca

[Abstract] A simple, rapid, and sensitive colorimetric microassay for inorganic phosphate $(\mathrm{Pi})$ relies upon the absorption at $660 \mathrm{~nm}$ of a molybdenum blue complex that forms upon reduction of an ammonium molybdate-Pi complex in acid. The method for determination of total Pi uses plant tissues that have been ashed at $500{ }^{\circ} \mathrm{C}$, whereas quantification of soluble $\mathrm{Pi}$ is performed with tissues extracted under mild acid conditions (which preserves acid-labile phosphate ester bonds).

\section{Materials and Reagents}

1. Plant tissues

2. $17.5 \mathrm{M}$ Glacial acetic acid

3. $12 \mathrm{M}$ Concentrated $\mathrm{HCl}$

4. $16 \mathrm{M}$ Concentrated $\mathrm{HNO}_{3}$

5. Sodium phosphate, monobasic $\left(\mathrm{NaH}_{2} \mathrm{PO}_{4}\right)$ (Bioshop, catalog number: SPM400)

6. Ascorbic acid (Bioshop, catalog number: AS0704)

7. Ammonium molybdate (Bioshop, catalog number: AMN333)

8. Zinc acetate (Sigma-Aldrich, catalog number: Z0625)

9. Quartz crucibles (Thermo Fisher Scientific, catalog number: 08-072 series)

10. Acid extraction solution (see Recipes)

11. Pi stock (for standard curve) (see Recipes)

12. Pi assay reagent (see Recipes)

\section{Equipment}

1. Crucible

2. Drying oven

3. Repeat pipetor

4. Isotemp Muffle Furnace (Thermo Fisher Scientific, model: 10-650-14)

5. Microcentrifuge

6. A computer supported microplate spectrophotometer (e.g., Spectromax Plus, Molecular Devices, Sunnyvale, CA, U.S.A.) 


\section{Procedure}

A. Total Pi (Hurley et al., 2010)

1. Acid wash crucibles by incubating for at least $1 \mathrm{~h}$ in $0.1 \mathrm{~N} \mathrm{HCl}$ at room temperature, then rinse with $\mathrm{dH}_{2} \mathrm{O}$ and dry.

2. Pre-weigh crucibles and place at least $60 \mathrm{mg}$ (fresh weight) of tissue in each.

3. Dry in oven at $50-80{ }^{\circ} \mathrm{C}$ for at least $16 \mathrm{~h}$ (e.g., overnight), and then record tissue's dry weight (mg) in each crucible.

4. Ash the tissue in the furnace using a temperature ramp program $\left(20 \mathrm{~min}\right.$ at $150^{\circ} \mathrm{C}, 1 \mathrm{~h}$ at $250{ }^{\circ} \mathrm{C}$, and $3 \mathrm{~h}$ at $500{ }^{\circ} \mathrm{C}$ ).

5. Weigh crucible and ash. Add $25 \mu \mathrm{l}$ of acid extraction solution per mg of ash, mix well, and centrifuge at $11,000 \times \mathrm{g}$ for $10 \mathrm{~min}$.

6. Dilute the supernatant 50 -fold in $\mathrm{dH}_{2} \mathrm{O}$.

7. Assay Pi using the Drueckes et al. (1995) protocol as modified for plant tissues (Bozzo et al., 2006) by preparing a standard curve over the range 1-133 nmol of Pi using the following template.

\begin{tabular}{|l|c|c|c|}
\hline Well \# & Vol of Pi stock $(3.3 \mathrm{mM})$ & Volume of $\mathrm{dH}_{2} \mathrm{O}$ & Amount of Pi added \\
\hline IA & $(\mu \mathrm{l})$ & $(\mu \mathrm{l})$ & $(\mathrm{nmol})$ \\
\hline IB & 0 & 40 & 0 \\
\hline IC & 2 & 38 & 6.6 \\
\hline ID & 4 & 36 & 13.2 \\
\hline IE & 8 & 32 & 26.4 \\
\hline IF & 12 & 28 & 39.6 \\
\hline IG & 16 & 24 & 52.8 \\
\hline IH & 20 & 20 & 66.0 \\
\hline $2 \mathrm{~A}$ & 24 & 16 & 79.2 \\
\hline $2 \mathrm{~B}$ & 30 & 10 & 99.9 \\
\hline $2 \mathrm{C}$ & 35 & 5 & 116.6 \\
\hline
\end{tabular}

a. Pipette 1-40 $\mu \mathrm{l}$ of unknown(s) into adjacent wells(s). Add $\mathrm{dH}_{2} \mathrm{O}$ to bring each well to $40 \mu$ final volume.

b. Add $200 \mu \mathrm{l}$ of Pi assay reagent to each well using a repeat pipetor.

C. Incubate at $37^{\circ} \mathrm{C}$ for $30 \mathrm{~min}$.

d. Measure $A_{660}$ values and use the Pi calibration (standard) curve to determine Pi content of unknowns.

e. Express the data as: $\mathrm{nmol} \mathrm{Pi} \mathrm{mg}^{-1}$ dry weight. 
B. Soluble Pi (Bozzo et al., 2006)

1. Extract snap-frozen tissues $(1: 5, w / v)$ with $1 \%(v / v)$ glacial acetic acid.

2. Centrifuge samples at $11,000 \times g$ for $10 \mathrm{~min}$.

3. Assay the supernatant for $\mathrm{Pi}$ as described above.

4. Esterified-Pi is calculated from the difference between total and free Pi concentrations.

\section{$\underline{\text { Recipes }}$}

1. Acid extraction solution

$30 \mathrm{ml} 12 \mathrm{M}$ concentrated $\mathrm{HCl}$

$10 \mathrm{ml} 16 \mathrm{M}$ concentrated $\mathrm{HNO}_{3}$

$60 \mathrm{ml} \mathrm{dH} \mathrm{H}_{2} \mathrm{O}$

2. Pi stock (for standard curve)

$3.3 \mathrm{mM} \mathrm{NaH}_{2} \mathrm{PO}_{4}$

3. Pi assay reagent

a. Ammonium molybdate reagent

b. Ammonium molybdate is added to an aqueous solution of $15 \mathrm{mM}$ zinc acetate to give a $10 \mathrm{mM}$ solution of molybdate. The solution is then adjusted to $\mathrm{pH} 5.0$ with $\mathrm{HCl}$. This solution is stored at $4{ }^{\circ} \mathrm{C}$ in the dark and is stable for several months.

c. Reducing reagent

A $10 \%$ (w/v) solution of ascorbic acid is adjusted to $\mathrm{pH} 5.0$ with $\mathrm{NaOH}$.

Note: This solution must be prepared fresh daily.

d. The Pi assay reagent is prepared by mixing one part of the ammonium molybdate reagent with four parts of the reducing reagent (prepare fresh daily).

\section{Acknowledgments}

Research in our laboratory has been generously funded by research and equipment grants from The Natural Sciences and Engineering Research Council of Canada (NSERC) and Queen's Research Chairs program to William Plaxton.

\section{$\underline{\text { References }}$}

1. Hurley, B. A., Tran, H. T., Marty, N. J., Park, J., Snedden, W. A., Mullen, R. T. and Plaxton, W. C. (2010). The dual-targeted purple acid phosphatase isozyme AtPAP26 is essential for efficient acclimation of Arabidopsis to nutritional phosphate deprivation. Plant Physiol 153(3): 1112-1122. 
2. Drueckes, P., Schinzel, R. and Palm, D. (1995). Photometric microtiter assay of inorganic phosphate in the presence of acid-labile organic phosphates. Anal Biochem 230(1): 173-177.

3. Bozzo, G. G., Dunn, E. L. and Plaxton, W. C. (2006). Differential synthesis of phosphate - starvation inducible purple acid phosphatase isozymes in tomato (Lycopersicon esculentum) suspension cells and seedlings. Plant Cell Environ 29(2): 303-313. 